We thank the Department of Health and Social Security for most of the long term funding of this programme and the Medical Research Council for supporting the staff responsible for its design and analysis. We also thank Pamela Hancox and Sheila Lachhman for secretarial help. Above all, we thank all the general practitioners and their receptionists.

\section{References}

1 Jarvis $M$. Gender and smoking: do women really find it harder to give up? Br $\mathcal{J}$ Addict 1984;79:383-7.

2 Raw M, Heller J. Helping people to stop smoking: the development, role and potential of support services in the UK. London: Health Education Council, 1984.

3 Chapman S. Stop-smoking clinics: a case for their abandonment. Lancet 1985;i:918-20.
4 Sutton SR, Hallett R. Experimental evaluation of the BBC TV series "So you want to stop smoking?" Addict Behav (in press).

5 Dyer N. So you want to stop smoking: results of a follow-up one year later. London: British Broadcasting Corporation, 1983. (BBC broadcasting research special report.)

6 Russell MAH, Wilson C, Taylor C, Baker CD. Effect of general practitioners' advice against smoking. BrMed f 1979;ii:231-5.

7 Jamrozik K, Vessey M, Fowler G, Wald N, Parker G, Van Vunakis H. Controlled trial of three different antismoking interventions in general practice. Br Med f 1984;288: 1499-503.

8 Russell MAH, Merriman R, Stapleton J, Taylor W. Effect of nicotine chewing gum as an adjunct to general practitioners' advice against smoking. BrMed J 1983;287:1782-5.

9 Jarvis MJ, Pedoe HT, Feyerabend C, Vesey C, Saloojee Y. Comparison of tests used to distinguish smokers from non-smokers. Am $\mathcal{f}$ Public Health (in press).
smis

10 Baker PJ, Nelder JA. The GLIM system, release 3. Oxford: Numerical Algorithms Groups, 1978. 11 Harrell FE. The LOGIST procedure. In: Joyner SP, ed. SUGI supplemental library users' guide. 1983 ed. Cary, North Carolina: SAS Institute Inc, 1983:181-202.

(Accepted 27 August 1987)

\title{
Audit Report
}

\section{Surveillance of body weight in general practice}

\author{
MICHAEL WEINGARTEN
}

This department carried out an audit of the surveillance of body weight in one small general practice with a stable population, which had a policy of weighing adults every three years. We tried to answer three questions: How many patients were weighed? How common was overweight? How did body weight vary with time?

How many patients were weighed? - Over seven years $252(78 \%)$ of the 323 adults over the age of 20 in the practice population had their weight recorded at least once and 149 patients (46\%) at least twice. Although only $9 \%$ of women (three out of 32) over the age of 56 had not been weighed, half of the men (20 out of 40) aged 20-35 were missed. The 149 patients who were weighed at least twice in seven

\footnotetext{
Department of Family Medicine, Kupat Holim Clinic Rosh Haayin, Tel-Aviv University, Israel

MICHAEL WEINGARTEN, MA, BM, senior lecturer
}

Correspondence to: Dr $M$ Weingarten, Department of Family Medicine, McMaster University, Hamilton, Ontario L8N 325, Canada. years weighed more on average $(65.9$ (SD 14.6) $\mathrm{kg}$ ) than the 103 patients who were weighed only once $(61 \cdot 8(12 \cdot 6) \mathrm{kg})$.

How common was overweight?-Both height and weight were recorded in only 158 patients, who were heavier $(65.7(13.4) \mathrm{kg})$ than the 94 others $(59.5(12 \cdot 2) \mathrm{kg}$ ). Body mass index (weight/ height $^{2}$ ) was calculated for these 158 patients; 43 of them were unequivocally obese (body mass index $>29$ ), and a further 57 were overweight with a body mass index of 25-29. Seventeen out of 36 (47\%) women aged $20-35$ but all 29 women aged over 56 were overweight or obese.

How did body weight vary with time? - Of the 149 patients whose weight was recorded twice or more, $106(71 \%)$ showed little change while the weight of $37(25 \%)$ changed by $10 \%-20 \%$ and that of six (4\%), including three patients with serious diseases, changed by over $20 \%$.

Measuring weight at every visit unless last done in the past two years will mean that most patients will have their weight measured regularly, but younger men may often be missed. For effective surveillance, however, height needs to be measured as well as weight.

(Accepred 9 September 1987) 